\title{
OBJECT-BASED IMAGE ANALYSIS OF WORLDVIEW-2 SATELLITE DATA FOR THE CLASSIFICATION OF MANGROVE AREAS IN THE CITY OF SÃO LUÍS, MARANHÃO STATE, BRAZIL
}

\author{
Hermann. J. H. Kux ${ }^{\text {a, } * \text {, Ulisses D. V. Souza }}{ }^{\text {a }}$ \\ ${ }^{\text {a }}$ INPE - National Institute for Space Research, Avenida dos Astronautas, 1758 - Jardim da Granja, 12.227-010 São José dos \\ Campos - SP, Brazil. (hermann@dsr.inpe.br, ulisses@dsr.inpe.br)
}

\section{Commission IV/3: Mapping from High Resolution Data}

KEY WORDS: WorldView-2, High-resolution images, Irregular occupation, Mangrove, Object-based Image Analysis, Highresolution images, Urban area.

\begin{abstract}
:
Taking into account the importance of mangrove environments for the biodiversity of coastal areas, the objective of this paper is to classify the different types of irregular human occupation on the areas of mangrove vegetation in São Luis, capital of Maranhão State, Brazil, considering the OBIA (Object-based Image Analysis) approach with WorldView-2 satellite data and using InterIMAGE, a free image analysis software. A methodology for the study of the area covered by mangroves at the northern portion of the city was proposed to identify the main targets of this area, such as: marsh areas (known locally as Apicum), mangrove forests, tidal channels, blockhouses (irregular constructions), embankments, paved streets and different condominiums.

Initially a databank including information on the main types of occupation and environments was established for the area under study. An image fusion (multispectral bands with panchromatic band) was done, to improve the information content of WorldView-2 data. Following an ortho-rectification was made with the dataset used, in order to compare with cartographical data from the municipality, using Ground Control Points (GCPs) collected during field survey. Using the data mining software GEODMA, a series of attributes which characterize the targets of interest was established. Afterwards the classes were structured, a knowledge model was created and the classification performed. The OBIA approach eased mapping of such sensitive areas, showing the irregular occupations and embankments of mangrove forests, reducing its area and damaging the marine biodiversity.
\end{abstract}

\section{INTRODUCTION}

In the last decades there was an increase on studies related to the urban dynamics in Brazil. (SOUZA, 2000). In the city of São Luis from the 1960s onwards there was a strong population growth, due to commercial and industrial activities concentrated in the region. A large part of this occupation was in areas of mangrove forests.

After the launch of the WorldView-2 satellite in October 2009, very high resolution images became available for detailed studies of cities in coastal areas. It is the first orbital sensor system with $0.46 \mathrm{~m}$ resolution in the panchromatic band and $1.84 \mathrm{~m}$ in the multispectral bands.

In order to process and analyze such large datasets, new methodologies were developed and tested. OBIA (Object-based Image Analysis) is a new methodological approach used for the classification of land use/land cover of urban areas with very high spatial resolution images (BLASCHKE \& KUX, 2007). Looking at an alternative software for users of this methodological approach, the Catholic University/Rio de Janeiro (PUC-RJ) and INPE, the Brazilian National Institute for Space Research, became partners for the development and application of an image analysis knowledge based system, the InterIMAGE, with open code and free access. (COSTA et al., 2010).

The objective of this work is to map mangrove forest areas of a section from Maranhão Island, classifying WorldView-2 images from this area using the InterIMAGE software and attributes selected by data mining techniques and implemented at the software GeoDMA.

\subsection{Object-Based Image Analysis (OBIA)}

For the analysis of high spatial resolution data, such as those from WorldView-2, use of the conventional pixel by pixel classification is quite limited, because images from these sensor systems present a high level of heterogeneity and internal class variation within the same scene. Blaschke (2010) reported the evolution of OBIA, presenting studies which applied this paradigm to several different applications. OBIA considers image classification based on objects such as topologic (neighborhood, context) and geometric (form, size) information.

Attributes such as form, size, texture, pattern and context are helpful for the classification, where solely spectral attributes are not sufficient and the knowledge of the interpreter is inserted to improve the image interpretation. The definition of the attribute space from a certain class is a task associated to a certain level of imprecision, which introduces a certain degree of uncertainty at the association of an object to a certain class. Benz et al. (2004) report that this uncertainty must be modeled, and this will be helpful for the evaluation of the classification.

\footnotetext{
* Corresponding author. Dr. Hermann Kux. hermann@dsr.inpe.br.
} 


\subsection{Image fusion}

The fusion of panchromatic with multispectral images of WorldView-2 scenes was done using the Principal Components methods, resulting in an image with $0.50 \mathrm{~m}$ spatial resolution.

\subsection{Ortho-rectification}

The orthorectification was made using the 3D rational polynomial method (TOUTIN, 2004), from software package PCI Geomatics v10.3.1, considering 55 GCPs for the entire area under study. The GCPs used for the geometric rectification were obtained during a field campaign in August 2011.

\subsection{Semantic network}

In order to compose the semantic network, the following land cover classes were defined for the test sites, based on the visual analysis of WorldView-2 images and on previous knowledge of the area by the interpreter.

The mangrove areas were discriminated in Arboreal vegetation (mangroves) and marsh area (Apicum, low vegetation type). Other classes: Bare soil, Roofs (Ceramic, Metal and Asbestos), Asphalt pavement, Tidal flat and Tidal channel.

\subsection{InterIMAGE}

InterIMAGE is knowledge-based free software for image interpretation. It was developed in the frame of a cooperation project between INPE, the Brazilian National Institute for Space Research, the Laboratory for Computer Vision of the Catholic University/Rio de Janeiro (PUC-RJ), and the Leibniz University of Hannover (Germany). According to COSTA (2009 and 2010), it inherited its knowledge structure, design and control mechanisms from the German system GeoAIDA (BÜCKNER et al., 2001), which consists of a further development of AIDA (Automatic Image Data Analyzer).

According to RIBEIRO (2010) the most important characteristics of InterIMAGE are its flexibility for the interpretation of multi-sensor images and the reduction of computer processing time and load for the image analysis.

The most recent version of InterIMAGE can be downloaded at http://www.lvc.ele.puc-rio.br/projects/interimage/.Among other operators for object extraction it contains: a segmenter from Baatz, the Checkerboard, a classifier by decision trees, an importer for vector files, topologic attributes which can be used at the decision rules of Top-Down and Bottom-Up operators (COSTA et al., 2010).

\subsection{Data Mining and GEODMA}

Data Mining consists on the application of computer algorithms over a data base aiming to abstract new and useful knowledge. WITTEN \& FRANK (2005) inform that these algorithms, according to certain paradigms, are based on techniques aiming to explore data to produce knowledge models which express patterns of data characteristics which can be extrapolated for the classification.

GeoDMA executes all processing phases needed to manipulate remote sensing data, including segmentation, extraction and selection of attributes, training, classification and exploratory data analysis.
For KORTING et al., (2009) the use of data mining tools can increase the analysis potential of remote sensing data applications when employed in urban areas, because of the variety of targets, difficulty to discriminate in these environments. Considering the large amount of objects to classify, more accurate techniques for the information extraction are required.

\subsection{Spatial analysis of geographic data}

The spatial analysis helps to process data to be used allowing also, through an exploratory analysis, to understand the attributes and variables which would explain certain processes. Crossing information obtained from satellite images with data from public management institutions, as well as data of environmental fragility obtained by geo-spatial inferences, can indicate the present state of environments under stress, such as certain mangrove covered areas.

\section{AREA UNDER STUDY}

The area under study is located in the Maranhão Island, NE Brazil, encompassing $831.7 \mathrm{Km}^{2}$.

To map mangrove forests, two test sites were chosen with a mixture of different stages of growth of this vegetation type, including those sections suffering strong human pressure as well as those recovering from possible impacts, which are representative for the present situation all over this island. The test sites are shown on Figure 1.

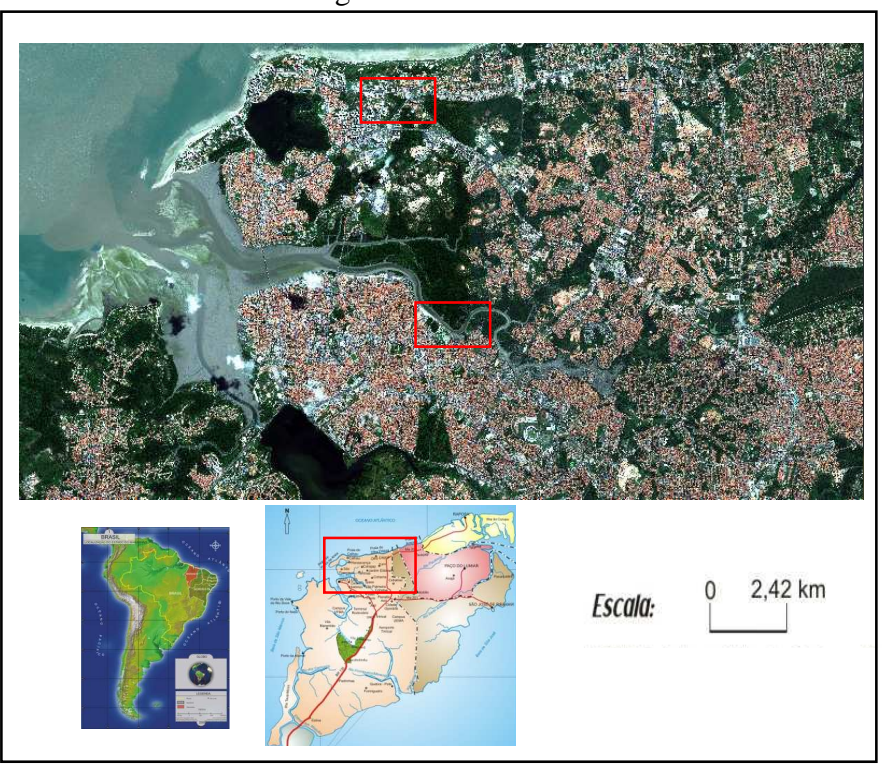

Figure 1 - Localization of test sites

Source: Adapted from WorldView-2 image dated July 10th 2010. (DIGITALGLOBE, 2010).

At the northern section of São Luis municipality there are fragile geologic structures of Quaternary age, which eases the landscape change by relief modeling agents of climatic, hydrologic and oceanographic origin. See further details about this issue in SOUZA \& FEITOSA (2009) and GERCO (1998).

Associated to these fragile structures there are mangroves, mainly at the margins of bays, inlets, river mouths, lagoons and coastal indentions. Such systems are functionally complex, highly resilient, resistant and stable, occurring exclusively in tropical areas. They are characterized by typical vegetation and 
sediments and are very important from an environmental and social-economic point of view (MOCHEL, 2006 p. 237).

In the test sites there are irregular occupations (blockhouses) close to the mangrove forests and marsh areas (Apicum) as well as houses and farther away also edifices. Figure 2 and 3 show one of the test sites with details of the heterogeneity from the area under study.

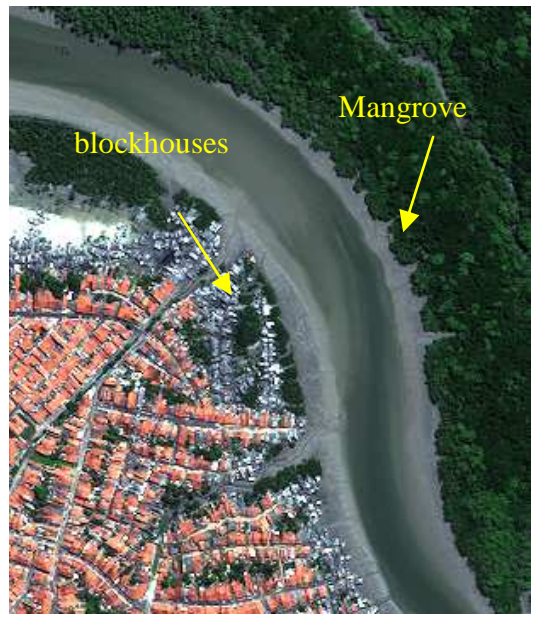

Figure 2 - Test site.

Source: adapted from WorldView-II image, dated July $10^{\text {th }}$ 2010. (DIGITALGLOBE, 2010).

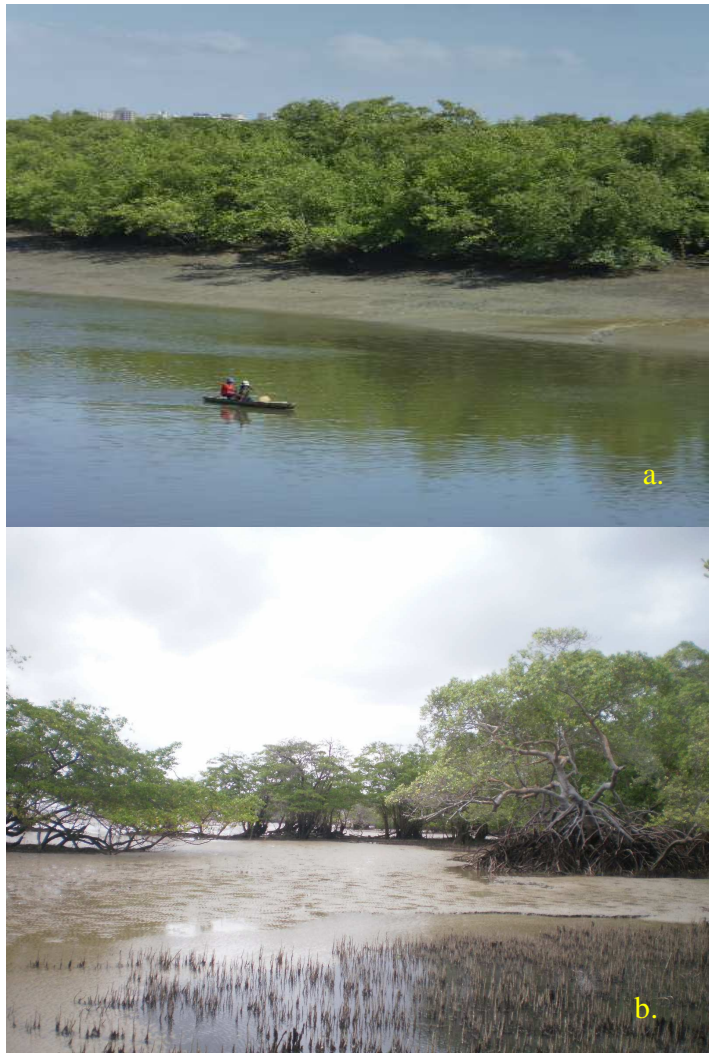

Figure 3: a. Dense mangrove; b. Degraded mangrove.

For this study, statistical data, information made available by governmental agencies and partner companies for this Project were used, besides ancillary academic studies mentioned above.

\section{METHODOLOGY}

The main methodological steps are presented in the flow diagram below. (Figure 4):

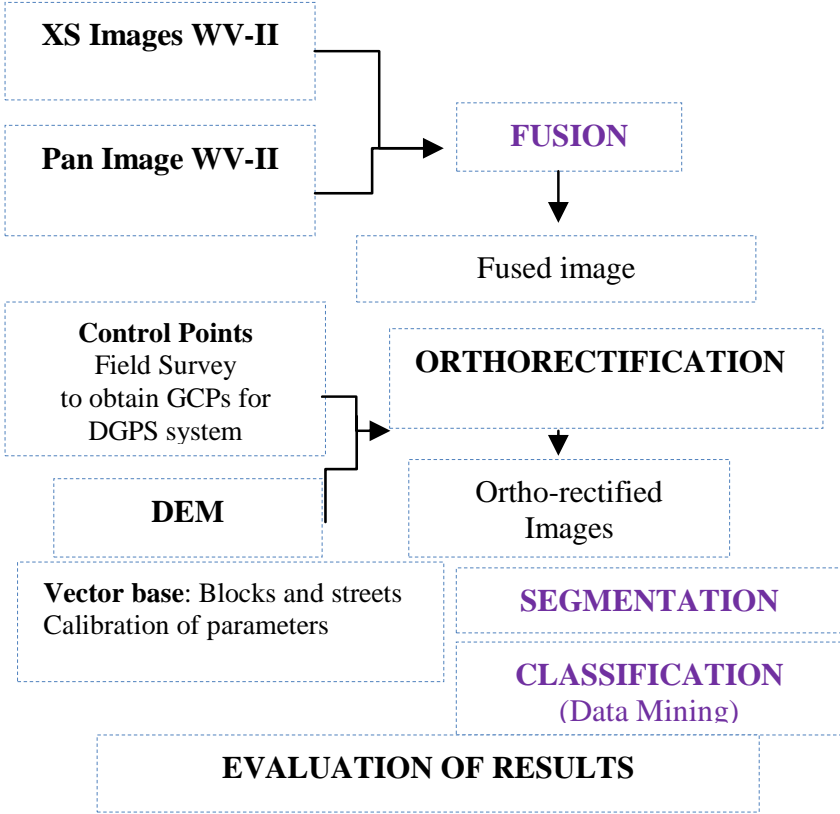

Figure 4 - Methodological procedures.

Materials used in this work:

1) Scenes from WorldView-II sensor obtained on June $10^{\text {th }}$ 2010 , with off-nadir angle $16^{\circ}$ and 11 bits radiometric resolution, delivered by company DIGITALGLOBE.

2) Vector files of blocks in the databank of the São Luis, from the planning agency of the city.

3) GCPs collected during Field survey in August 2011 with TOPCON Hiper L GPS geodetic equipment.

4) Contour lines in vector format, $1 \mathrm{~m}$ equidistance of contours, for the São Luis region.

The following software was used for image processing: ENVI 4.7 (ITT, 2009), used for fusion and cutting of both test sites; PCI Geomatics V10.3.1 (PCI Geomatics, 2010) to work with the Digital Elevation Model and control points, followed by WorldView-2 image ortho-rectification, InterIMAGE v1.27 (InterIMAGE 2010) and GeoDMA for the exploratory analysis of image attributes and land cover classification.

For the spatial analysis the software SPRING 5.1.7, developed at INPE, was used to generate vulnerability maps of mangrove areas of the northern section from the Maranhão Island.

\section{RESULTS}

Based on the attributes chosen, a thematic land cover map was generated from the classification of WorldView-2 data, using InterIMAGE v1.27 and data mining of GeoDMA. This software allowed a supervised analysis of the different attributes and to define the best ones and the thresholds used for the classification. 
During the implementation of the hierarchical network, the classification executed at InterIMAGE was considered, using the Top-Down and Bottom-Up approach. The option was a network with few levels and many leaf nodes which allow lower computer costs (RIBEIRO, 2010).

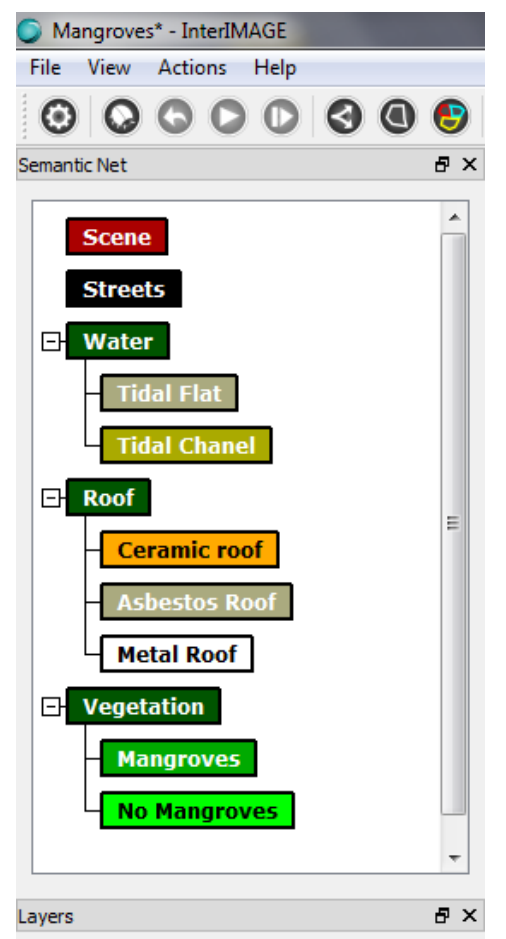

Figure 5: Semantic network elaborated at InterIMAGE.

After structuring the network (Figure 5), the segmentation of the scene was performed (Figure 6), where the leaf nodes perform a logic selection and transmit to the parent-node a reduced number of hypotheses, for later object classification at the Bottom-Up phase. The conflicts are solved attributing membership values to each class, prioritizing those attributes which defined classes with less omission and commission errors.

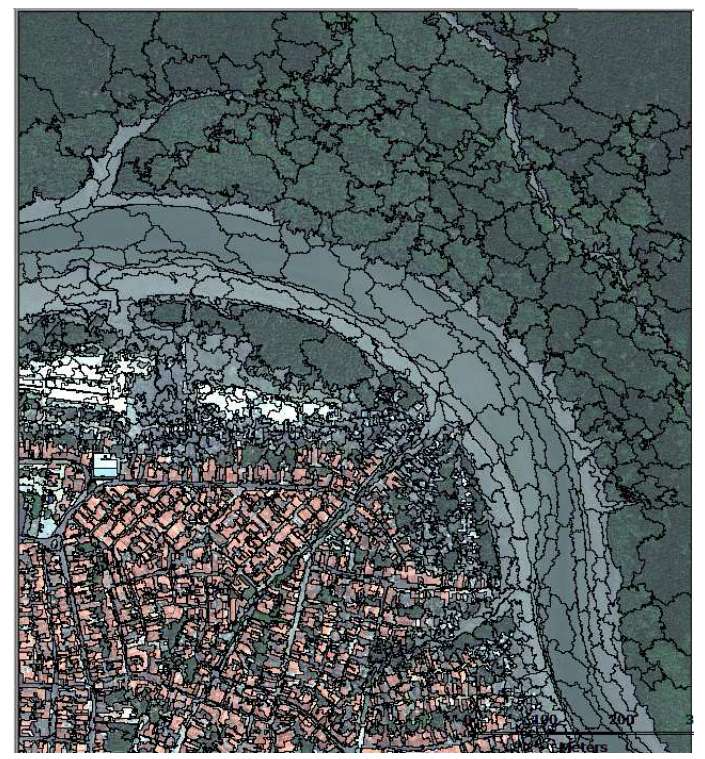

Figure 6: Segmented image of test site.
At the above mentioned test sites and after an exploratory analysis of data (Figures 7 and 8), considering both training samples and test with the C.45 algorithm, it was possible to determine attributes which best discriminate the targets mapped (Figure 9).

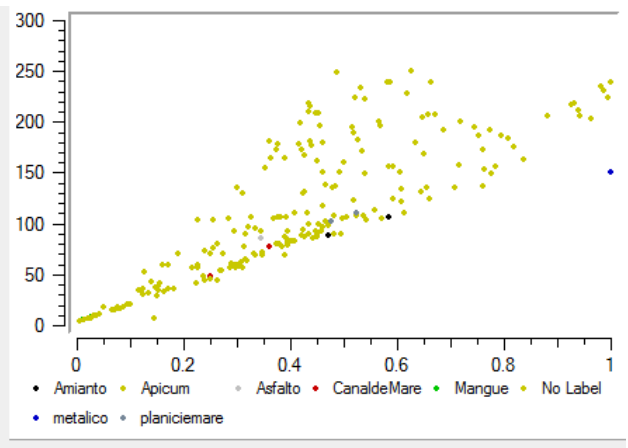

Figure 7: Exploratory analysis by samples.

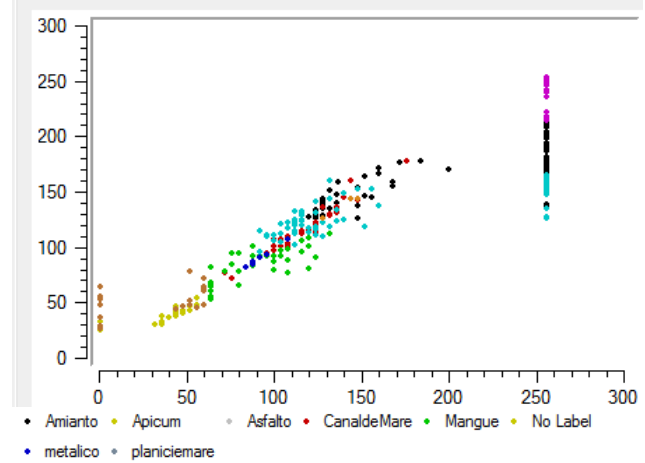

Figure 8: Exploratory analysis using a decision tree.

$$
\begin{aligned}
& \text { rp_mean_1_ } n<=0.3300127089 \\
& \text { | P_area }<=500.5000000000 \\
& \begin{array}{l}
\text { | } \text { rp_stddev_2_n }<=0.2708886862 \\
\text { | | | rp_mean_2 }<=67.2668380737 \rightarrow 7
\end{array} \\
& \begin{array}{l}
\text { | | | rp_mean_2 }<=67.2668380737 \rightarrow>7 \\
\text { | || } \mid \text { rp_mean_2 }>67.2668380737 \rightarrow 1
\end{array} \\
& \text { | | rp_stddev_2_n }>0.2708886862 \\
& \text { | | | rp_mean_2_ } n<=0.1993619055 \\
& \text { | | | | rp_mean_2_n }<=0.1483090073 \rightarrow 7 \\
& \text { | | | | rp_mean_2_n }>0.1483090073 \\
& \text { | | | | | rp_stddev_1_ } n<=0.4427264929 \rightarrow 2 \\
& \text { | | | | | rp_stddev_1_n }>0.4427264929 \\
& \text { | } 1 \text { rp_stddev_ } 0<=36.7712402344 \rightarrow 7 \\
& \text { | } 1 \text { p_stddev_0 } 0<=36.7712402344 \\
& \text { | | | | | | | P_compacity }<=0.0882763267 \rightarrow 2 \\
& \text { | | | | | | | p_compacity >0.0882763267 } \rightarrow 7 \\
& \text { | | rp_mean_2_n > } 0.1993619055 \\
& \text { | | | | rp_stddev_2_ } n<=0.5379980803 \rightarrow 2 \\
& \text { | | | | rp_stddev_2_n }>0.5379980803 \\
& \text { | | | | rp_mean_2 }<=83.6195831299 \rightarrow 7 \\
& \text { | I r_mean_2 > 83.6195831299 } \rightarrow 2
\end{aligned}
$$

Figure 9: Model of a decision tree generated at GeoDMA

After the evaluation of attributes from the scene as well as of the decision tree generated, the final scene classification was performed (Figure 10), followed by the extraction of the Mangrove forests (Figure 11). Considering the confusion matrix, a Kappa index value of 0.93 was found for the map generated. The Producer's and User's accuracies obtained for the land cover classes are at Table 01 .

Table 01: Producer's and User's accuracies

\begin{tabular}{|l|c|c|}
\hline Land cover classes & Producer's accuracy & User's accuracy \\
\hline Streets & 0.94 & 0.86 \\
\hline Tidal Flat & 0.82 & 0.74 \\
\hline Tidal Chanel & 0.78 & 0.70 \\
\hline Ceramic roof & 0.92 & 0.64 \\
\hline
\end{tabular}




\begin{tabular}{|l|l|l|}
\hline Asbestos roof & 0.75 & 0.57 \\
\hline Metal roof & 0.66 & 0.64 \\
\hline Mangroves & 0.95 & 0.96 \\
\hline No mangroves & 0.82 & 0.84 \\
\hline
\end{tabular}

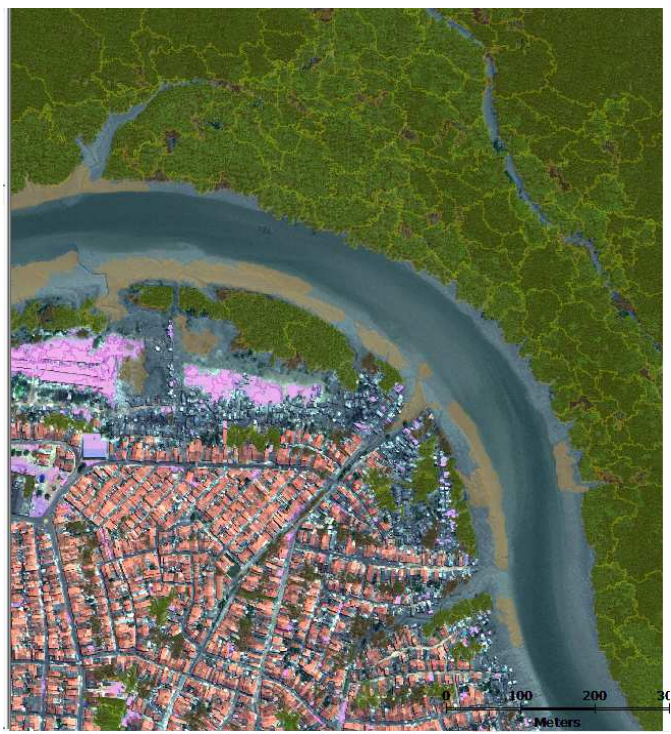

Figure 10: Final classification of the scene.

Texture attributes implemented at InterIMAGE v1.27 were used for classification, taking into account the difference among classes related to it. The result of the scene classified was improved because the attributes related to both channels Yellow and Red-Edge are better defined, eliminating confusions which occurred in the past, for instance, with classes Ceramic roof and Bare soil.

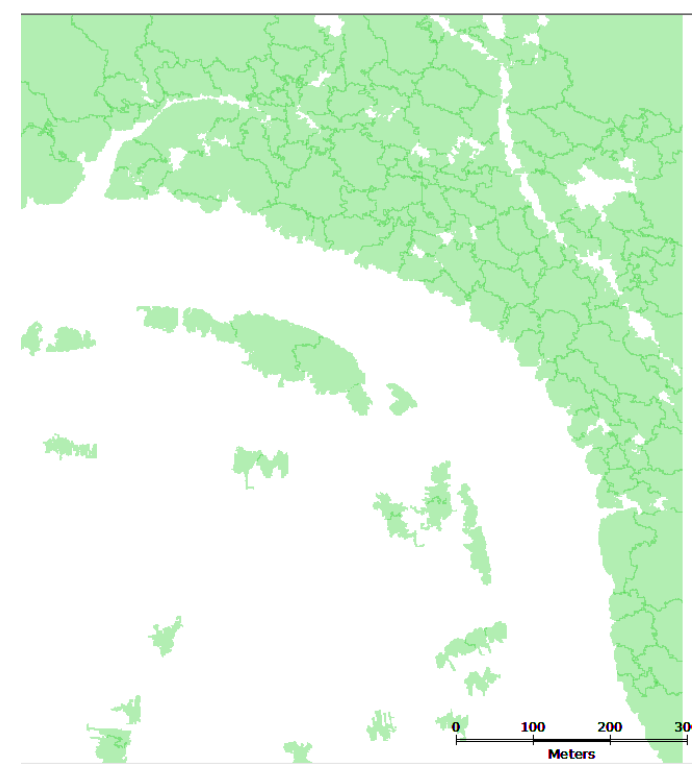

Figure 11: Extraction of Mangroves from classification.

From the evaluation of classification one perceives that land cover classes Apicum (low vegetation) and mangroves (arboreal vegetation) are spectrally confusing. Nevertheless, when considering the NDVI, this index helps with the discrimination of such targets, specially when using the Red Edge channel. This is due to the fact that this channel is positioned spectrally at the absorption end from the red and beginning of the infrared wavelength for part of vegetation. So it is partially sensitive to the spectral behavior of different vegetation types from this region (Figure 12), which was expected for the spectral bands of this satellite system (Figure 13).

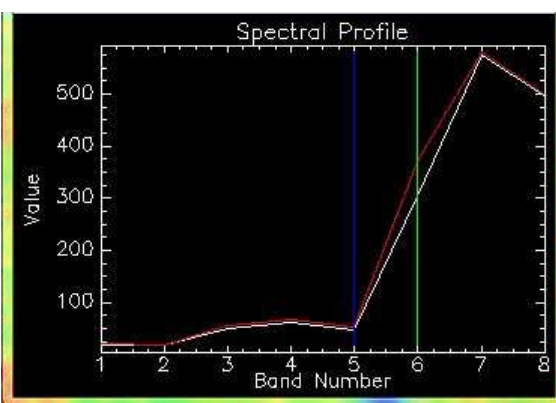

Figure 12: Graph of gray levels.

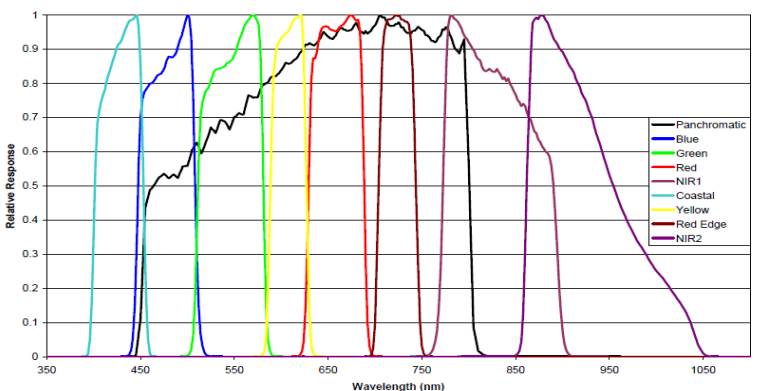

Figure13 - Spectral response of WorldView-2 channels. Source: Padwick et al., (2010)

\section{CONCLUSION}

It is concluded that WorldView-2 data facilitates the identification of different vegetation types, including mangrove forests, due to the new multispectral bands available. The combination of both spatial and spectral resolution allows a more precise discrimination among the targets mapped, allowing further detail at land cover maps.

The use of InterIMAGE software (image classification) and GeoDMA to elaborate the decision tree enabled a fast classification from improved image attributes, using the texture algorithm implemented at InterIMAGE allowing the separability of class mangrove.

A companion paper authored by Souza \& Kux at this congress, presents further details about the mangrove classification.

\section{References}

BENZ, U. C.; HOFMANN, P.; WILLHAUCK, G.; LINGENFELDER, I.; HEYNEN, M., 2004. Multi-resolution, object-oriented fuzzy analysis of remote sensing data for GISready information. ISPRS Journal of Photogrammetry and Remote Sensing, v. 58, n. 3-4, p. 239-258.

BLASCHKE, T., Object based image analysis for remote sensing. ISPRS Journal of Photogrammetry \& Remote Sensing, n. 65, p. 2-16, Aug. 2010.

BÜCKNER, J.; STAHLHUT, O.; PAHL, M.; LIEDTKE., C.-E., 2001. GeoAIDA - A knowledge based automatic image data analyzer for remote sensing data. In: INTERNATIONAL ICSC CONGRESS ON COMPUTATIONAL INTELLIGENCE: 
METHODS \& APPLICATIONS, 2. Bangor, Wales, United Kingdom. Proceedings.... Millet, Alberta: ICSC. p.19-22

BLASCHKE, T.; KUX, H. J. H., 2007. Sensoriamento remoto e SIG avançados - novos sistemas sensores: métodos inovadores: Oficina de Textos, São Paulo, $2^{\mathrm{a}}$ ed. 303 p.

COSTA, G. A. O. P. A knowledge-based approach for automatic interpretation of multidate remote sensing data. 2009. 149 p. PhD-Thesis in Electric Engineering) - Pontifícia Universidade Católica do Rio de Janeiro (PUC-Rio), Rio de Janeiro, 2009.

COSTA, G. A. O. P.; FEITOSA, R. Q.; FONSECA, L. M. G.; OLIVEIRA, D.; FERREIRA, R. S.; CASTEJON, E. F., 2010. Knowledge-based interpretation of remote sensing data with the InterIMAGE system: major characteristics and recent developments. In: GEOGRAPHIC OBJECT BASED IMAGE ANALYSIS (GEOBIA), June $29^{\text {th }}-$ July $2^{\text {nd }} 2010$, Ghent, Belgium, International Archives of Photogrammetry, Remote Sensing and Spatial Information Sciences, vol. XXXVIII-4/C7. Ghent University. CD-ROM.

DIGITALGLOBE. White Paper - The benefits of the 8 Spectral Bands of WorldView-II. March2010a. Available at: http://Worldview2.digitalglobe.com/docs/Worldview-2_8Band_Applications_Whitepaper.pdf.

GEODMA - Geographical Data Mining Analysis, Developed by Thales Korting. Available at:

http://www.dpi.inpe.br/geodma/?lingua=portugues .

GERCO. GOVERNO DO ESTADO DO MARANHÃO. SECRETARIA DE ESTADO DO MEIO AMBIENTE E RECURSOS HÍDRICOS, 1998. Macrozoneamento do Golfão Maranhense - diagnóstico ambiental da microrregião da aglomeração urbana de São Luís: estudo sócio-econômico e cultural. São Luís: Coordenadoria de Programas Especiais/Programa Estadual de Gerenciamento Costeiro.

ITT Visual Information Solutions, 2009. ENVI 4.7, version 4.7. Boulder, Colorado, EUA.

KORTING, T. S.; FONSECA, L. M. G.; ESCADA, M. I. S.; CÂMARA, G. GeoDMA: um sistema para mineração de dados de sensoriamento remoto. In: SIMPÓSIO BRASILEIRO DE SENSORIAMENTO REMOTO, 14, 2009, Natal. Anais... São José dos Campos: INPE, 2009. p. 7813-7820. Disponível em: http://marte.dpi.inpe.br/col/dpi.inpe.br/sbsr@80/2008/11.17.21. 17/doc/7813-7820.pdf.

MOCHEL, F.R.C, 2006. Avaliação das potencialidades e fragilidades das áreas de manguezal para a implementação do ecoturismo usando ferramentas de sensoriamento remoto em Curupu - MA. Revista Caminhos de Geografia. São Luís, v.22, n. 17 , p. $237-243$.

PADWICK, C.; 2010. DESKEVICH, M.; PACIFICI, F. SMALLWOOD, Scott. Worldview-2 Pan Sharpening. In: Proceedings... ASPRS 2010 Annual Conference, San Diego, California. April 26-30.

PCI GEOMATICS ENTERPRISES INC, 2010. PCI Geomatica-10, version 10.3.1. Richmond Hill, Ontario, Canada.
RIBEIRO, B.M.G., 2010. Avaliação de Imagens WorldView-II para o mapeamento da cobertura do solo urbano utilizando o sistema InterIMAGE. Dissertação (Mestrado em Sensoriamento Remoto). INPE - Instituto Nacional de Pesquisas Espaciais, São José dos Campos, available at: http://mtcm19.sid.inpe.br/col/sid.inpe.br/mtc-

m19@80/2010/08.03.12.52.20/doc/Dissertacao_BMGR_final.p df.

SOUZA, M. L., 2000. Um estudo sobre a Problemática Sócioespacial nas Metrópoles Brasileiras. Bertrand Brasil, Rio de Janeiro, 368p.

SOUZA, U.D.V.; FEITOSA, A.C. Ocupação e uso da zona costeira do Estado do Maranhão. In: Encontro de Geógrafos da América Latina (EGAL), 12.,2009, Montevidéu, Uruguai, Anais... XII EGAL, 2009. Trabalhos completos, p. 2415-2430. CD-ROM, Online. ISBN 78-14-00012-3. Available at: http://www.egal2009.com/ (10 Out. 211).

TOUTIN, T.; Review article: geometric processing of remote sensing images: Models, Algorithms and Methods. International Journal of Remote Sensing, vol. 25 (10), 1893-1924, May 2004.

WITTEN, I.H.; FRANK, E., 2005. Data mining - practical machine learning tools and techniques (2.ed.). Morgan Kaufmann, San Francisco. 558 p. ISBN (0-12-088407-0).

\section{Acknowledgements}

We acknowledge company DIGITALGLOBE for the WorldView-2 image and Fundação de Amparo a Pesquisa do Maranhão, FAPEMA, for the scholarship granted to the coauthor. 